\title{
Design of Decision Support System in Selecting Cement Vehicles Based on Driver Performance, Expeditor Performance, and Waiting Time
}

\author{
Ihsan Prasetya $^{1}$ and I Nyoman Pujawan ${ }^{1}$
}

\begin{abstract}
Current logistics developments affect a process in any company using third party logistics. Third party logistics is a distribution service, warehousing carried out by third parties (outsourcing). Third party logistics in its business practices has been owned by many parties. PT $Z$ is one of the companies engaged in the cement industry which has a lot of cooperation with third party logistics. PT Z has assessed the expeditor partners. The problem that occurs is the problem of each driver and expeditor in the field agreeing to the same. There are some expeditors who have good performance and vice versa. In the midst of tight business third-party logistics resulted in each expeditor competing with each other and providing the best service to his clients. This research makes a decision support system by examining aspects that make the consideration of the selection of drivers and expeditors to be used for the transport of cement in PT Z. The method used in this study is the analytical hierarchy process (AHP) according experts' opinion in cement industry. Research uses decision support systems based on web information systems as an application method. This research can determine the choice of the driver and expeditor who has the best performance to carry out the cement transportation process at $P T Z$ by considering the driver's waiting time. Drivers who have better results will get greater opportunities (priority) chosen to transport cement.
\end{abstract}

Keywords-Supply Chain, Third-Party Logistics, Decision Support Systems, AHP.

\section{INTRODUCTION}

Nowadays, the cement industry is an industry that has an important role in ensuring the cement construction of facilities and infrastructure in the midst of people's lives. Every development project that is carried out at this time requires cement as one of the raw materials. This makes cement a highly prioritized raw material in the community.

PT Semen Indonesia (Persero) Tbk, previously known as PT Semen Gresik (Persero) Tbk, is a State-Owned Enterprise (BUMN) that is engaged in building materials and cement industries. The company acts as a Strategic Holding Company with various business lines offering complete solutions in development [1].

One of the business processes found in the cement industry is the supply chain or better known as the supply

\footnotetext{
${ }^{1}$ Ihsan Prasetya and I Nyoman Pujawan are with Department of Management Technology, Institut Teknologi Sepuluh Nopember, Indonesia. Email: . ihsanprasetya @gmail.com; pujawan@gmail.com.
}

chain. Whereas in the supply chain there are several flows from upstream to downstream.

In the cement industry, the Company's production capacity continues to experience growth. At present, the Company has 14 Integrated Cement Plants spread in Indarung (West Sumatra), Tuban (East Java), Pangkep (South Sulawesi), Rembang (Central Java) and Quang Ninh (Vietnam) with a total installed capacity of 31.8 million Tons of cement per year [1].

The cement production process is carried out through several stages. Among them is the breakdown of raw materials, blending, preheating, combustion, cooling and packaging in accordance with Figure 1.

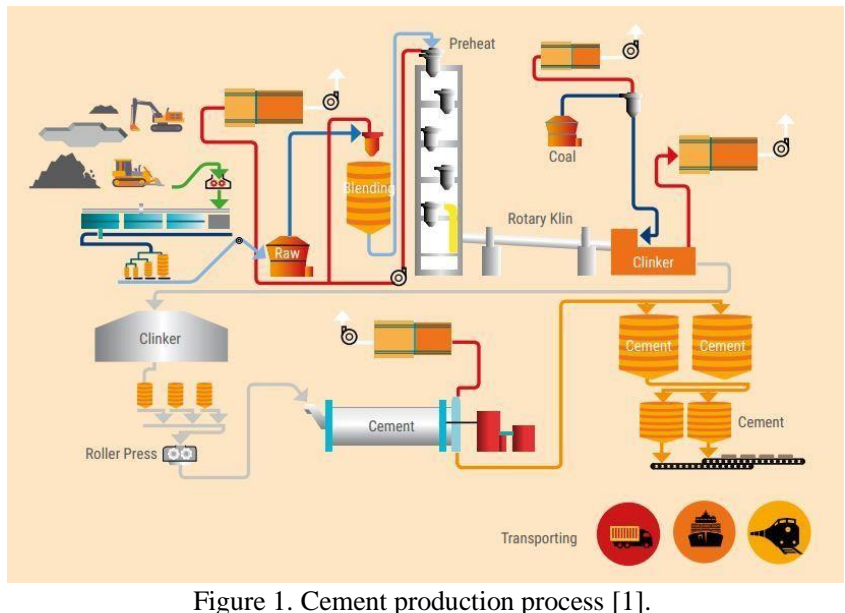

In 2017, one of the strategic initiatives implemented in order to support the achievement of the Company's performance is Move Closer to Customer, which is closer to customers by implementing Supply Chain Management (SCM). In implementing SCM, the Company integrates a series of business activities in the supply chain to create added value for customers, both in the form of products and services by using the resources in the supply chain [1]. The common problems in the cement industry include distribution of network configurations, distribution strategies, inventory management, and regulation of fund flows. The supply chain execution is to regulate and coordinate the movement of material, information andfunds among the supply chain.

In this research, the topic will be focused on decision management systems in supporting the selection of fleets 
that will transport cement. The researcher hopes to develop a decision system to determine which fleet will be prioritized in transporting cement based web information systems. This study uses a weighting theory taking into account the driver's performance, expeditor's performance, and waiting time for a fleet to obtain a cement transportation warrant.

The results of this study are in the form of a web information system based decision support system in determining the selection of trucks to be used to transport cement. The impact that will be produced is the priority of the choice of truck drivers who have high performance values compared to truck drivers who have low performance values. This will certainly be a positive value for the third-party logistics and corporate finance expedition competition.

In order to overcome the tight competition in the cement industry, while pursuing opportunities for growth in the future, the Company developed a strategy to win business competition by optimizing the advantages possessed [1].

Competition in the cement industry in Indonesia is increasingly tight every year. Industrial players who increasingly supply cement in the market are increasingly abundant, so there is a tendency for an imbalance between supply and demand levels. Moreover, the level of public consumption tends to stagnate. Although the demand trend began to show improvement, the tight competition in the market was unavoidable. Business actors respond with selling price competition to meet consumer rationality related to price and purchasing power [1].

Basically, cement transport trucks can be differentiated based on the products they transport. There are 2 cement products marketed today, namely cement bag truck in accordance with Figure 2 and bulk cement in accordance with Figure 3.

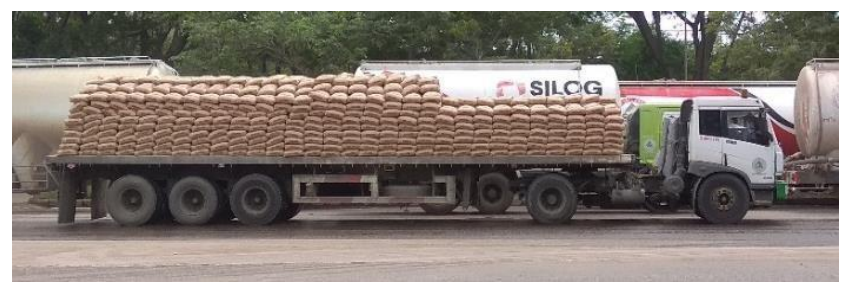

Figure 2. Cement bag truck

In reality, not always the goods produced by producers to get to consumers must pass through the distributor. However, in modern developments distribution activities play an important role. Moreover, with the advancement of closer transportation technologies between nations closer. This influences the importance of distribution, which is increasingly important because the goods are in the country but also consumers who are abroad. Supply chain is a network of companies that work together to create and deliver a product to the end user.

The company can consist of suppliers, stores, retailers, distributors and various other logistics support companies.
Supply Chain Management is a management method, tool or approach [2].

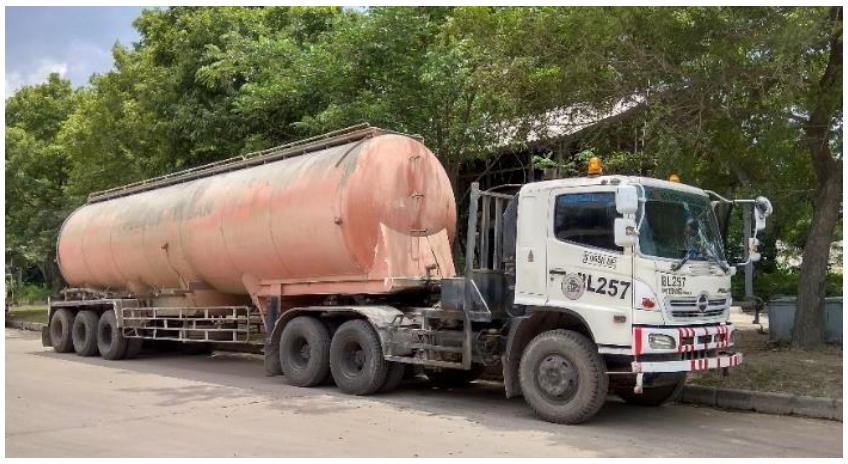

Figure 3. Cement bulk truck

In the supply chain there are usually 3 types of flow that occur in it. First, the flow of goods from upstream to downstream. Second, the flow of money flows from downstream to upstream. Third, the flow of information that can occur from upstream to downstream or vice versa [2].

Supply chain management is a method or approach to managing the flow of products, information and money in an integrated manner involving parties, ranging from upstream to downstream consisting of suppliers, vendors, distribution activities and logistics services [2].

The Analytical Hierarchy Process was developed by Dr. Thomas Saaty, has been widely used and applied by several researchers for multi-criteria decision making. AHP offers a solution through an alternative approach when dealing with multiple objective problems [3].

The basic idea of the AHP working principle according to (Marimin, 2005) [4] is as follows:

The problem to be solved is broken down into its elements, namely the criteria and alternatives, then arranged into a hierarchical structure. The MADM problem hierarchy (Multiple Attribute Decision Making), at the peak level there is only one element, namely the ultimate goal of the problem [5].

Criteria and alternatives are assessed through pairwise comparisons, for various problems the best scale in expressing opinions is on a scale of 1 to 9 [6].

For each criterion and alternative, pairwise comparisons are needed. Relative comparison values are then processed to determine the relative rank of all alternatives. Qualitative criteria and quantitative criteria can be compared according to predetermined judgment to produce weights and priorities. All elements are grouped logically and are warned consistently according to a logical criterion [4].

In general, the core business of a company will be the focus of a company, therefore the company collaborates in outsourcing with other businesses that are experts in their fields [7]. The business model of third-party logistics for logistics and physical distribution only developed in the UK in the early 1990s [8]. Third-party logistics has been widely promoted by the phenomenon of outsourcing, where 
companies are increasingly dependent. The growth of logistics outsourcing is mainly due to the benefits of reducing costs, improving performance, focusing on their core business and building virtual companies through corporate strategy [9].

TABLE 1.

ADVANTAGES AND DISADVANTAGES OF USING 3PL

\begin{tabular}{|c|c|}
\hline Advantages & Disadvantages \\
\hline Cost reduction & $\begin{array}{l}\text { Loss of control over the logistics } \\
\text { function }\end{array}$ \\
\hline $\begin{array}{l}\text { Improved efficiency, service and } \\
\text { flexibility }\end{array}$ & Impact on in-house workforce \\
\hline Focus on core competency & $\begin{array}{l}\text { More distance from clients- loss of } \\
\text { personal touch }\end{array}$ \\
\hline Freeing up resources & $\begin{array}{l}\text { Discontinuity of services of a } 3 \mathrm{PL} \\
\text { provider }\end{array}$ \\
\hline $\begin{array}{l}\text { Elimination of infrastructure } \\
\text { resources }\end{array}$ & $\begin{array}{l}\text { Differences of opinion or } \\
\text { perception of the service level of } \\
\text { the 3PL provider }\end{array}$ \\
\hline \multicolumn{2}{|l|}{ Risk- sharing } \\
\hline \multicolumn{2}{|l|}{ Better cash flow } \\
\hline $\begin{array}{l}\text { Access to resources not available } \\
\text { at one's own organization }\end{array}$ & \\
\hline
\end{tabular}

There are several advantages and disadvantages of 3PL in accordance with Table 1. The benefits of using 3PL can produce important benefits such as being able to reduce logistics costs, make fixed logistics assets, improve order fulfillment, shorten the average order cycle time and shorten the financial cycle [10]. Transportation and warehousing services are the top candidates in the function of third-party logistics, which are two important functions in logistics [11]. Perception of the level of importance of logistics activities can be seen in Table 2 .

TABLE 2.

PERCEIVED LEVEL OF IMPORTANCE OF LOGISTICS ACTIVITIES PERFORMED BY 3PLPROVIDERS

\begin{tabular}{lc}
\hline \multicolumn{1}{c}{ Activity } & Percentage 3PL Providers \\
\hline Transportation & 90.61 \\
Warehousing & 83.27 \\
Purchasing & 81.22 \\
Consolidation and distribution & 81.22 \\
Inventory management & 70.61 \\
Product returns & 47.35 \\
Order management & 70.61 \\
Cross docking & 67.76 \\
Packaging & 69.8 \\
\hline \hline
\end{tabular}

Performance is a measure of performance. In this study there were 3 performance references including driver performance, expeditor performance, and queue time. Calculations that will be used in this study:

$$
\mathrm{G}=\mathrm{PP}+\mathrm{PE}+\mathrm{WA}
$$

where $G$ is the result of weight calculation, PP is the driver's performance value, $\mathrm{PE}$ is the expeditor's performance value, and WA is the waiting time's value

Driver's performance is a value that is owned by a driver on his performance during work. The driver's performance has a range of values from $0-100$.

The parameters contained in the driver's performance criteria include the timeliness of delivery, compliance with regulations, skills, and safety.

$$
\begin{aligned}
& P P=\left(\left(A \_P \times \mathrm{W} A p+B p \times \mathrm{W} B p+C p \times\right.\right. \\
& W C p+D p \times W D p) / 4) \times W P P
\end{aligned}
$$

The driver's performance value can be seen as illustrated by the equation 2 with the description PP is the driver's performance, Ap is the timeliness of delivery, Bp is compliance with regulations, $\mathrm{Cp}$ is skill, Dp is safety. WAp is the weight of the timeliness of delivery, $\mathrm{WBp}$ is the weight of compliance with regulations, WCp is the skill weight, and WDp is the weight of safety. WPP is the weight of the driver's performance.

Expeditor's performance is a value that is owned by the expeditor on the company's performance during work. Expeditor's performance is obtained from the average driver's performance value found in a company.

$$
P E=\left(\frac{1}{n} \sum_{i=1}^{n} K_{i} \times W_{i}\right) \times W P E
$$

Expeditor's performance value can be seen in equation 3 with PE description is expeditor's performance, $n$ is the number of criteria of an expeditor, $\mathrm{K}$ is the value of a criterion, $\mathrm{W}$ is the weight of a criterion, and WPE is the expeditor's performance weight

Waiting time is the time when a truck has entered the factory area empty (without charge) and is still waiting until it gets an order to transport cement. The waiting time value is denoted by WA. The queue time is denoted by WWA. The symbol $\mathrm{w}$ is the length of time the truck waits from entering the cargo pool until it gets permission to load, according to equation 4 .

$$
W A=w \times W W A
$$

Decision support system is a system that is able to help in solving various problems with semi-structured and unstructured conditions, where no one knows for sure how decisions should be made [12]. The concept of decision support systems has evolved mainly from theoretical studies of organizational decision making conducted at the Carnegie Institute of Technology in the late 1950s and early 1960s [13].

Organizations in a turbulent and high-speed business environment face persistent changes in demand, competition, technology and regulation [14]. 


\section{METHOD}

\section{A. Observation of Processes in the Field}

Based on the background and debate in the literature studio that has been carried out, it is known the factors involved in the process of transporting cement using trucks. At this time the formulation of the problem was made which began with the approval of the factors agreed upon in the process of selecting a decision support system. Determination of the criteria used in this study is based on various reference sources. Observation in the field to match suggestions from existing sources with data occurring in the field.

\section{B. Survey Phase with Questionnaire}

At this stage a questionnaire was filled out by several experts in the field of transportation at PT Semen Indonesia. Experts fill out questionnaires with ranking methods for third-party logistics selection criteria and paired comparison methods to determine the level of importance between attributes and sub attributes.

The speakers in this study were 3 respondents. First, from Inventory Management in Tuban Factory. Secondly, from Transportation Ops II. Third, from Regional II Transportation Operations.

Phase filling out the questionnaire was done twice. First, the questionnaire concerns the priority of expeditor selection criteria. The filling out of this questionnaire aims to determine the criteria that are in accordance with the operational process of transportation in the Tuban factory area, PT Semen Gresik. Secondly, this questionnaire contains a comparison of the driver's performance, expeditor's performance, and waiting time. In this second questionnaire, there are filling in paired comparisons for sub attributes of driver performance and expeditor performance.

The process of filling out the questionnaire was done to get the value based on the opinions of each respondent. Then the data obtained will be used for the next process, namely the calculation stage of criteria selection and AHP weight calculation.

\section{Stage of Criteria Selection Calculation}

At this stage the criteria selection calculation is carried out. At this stage there are several expeditor selection criteria, according to predetermined criteria.

\section{AHP Weight Calculation Stage}

At this stage the decision system model is made by using a weighting method on the variables of driver performance, expeditor performance, and waiting time. At this stage also make a database for the driver, expeditor, and waiting time.

\section{E. Stage of Conclusions and Recommendations}

This stage is the final stage of the research that explains the results of the research obtained. The results of this study are expected to find solutions to the problems raised.
TABLE 3.

RANKING OF 3PL SELECTIONFACTORS

\begin{tabular}{lccc}
\hline \hline \multicolumn{1}{c}{ Selection Factors } & $\mathbf{2 0 0 3}$ & $\mathbf{1 9 9 9}$ & $\mathbf{1 9 9 4}$ \\
\hline Price & 1 & 4 & 11 \\
Reliability & 2 & 2 & 2 \\
Service quality & 3 & 1 & 1 \\
On-time performance & 4 & 3 & 3 \\
Cost reduction & 5 & 6 & 14 \\
Flexibility and innovation & 6 & 5 & 7 \\
Good communication & 7 & 10 & 4 \\
Management quality & 8 & 7 & 8 \\
Location & 9 & 12 & 13 \\
Customize service & 10 & 13 & 9 \\
Speed of service & 11 & 8 & 6 \\
Order cycle time & 12 & 9 & 10 \\
Easy to work with & 13 & 16 & 12 \\
Customer support & 14 & 11 & 5 \\
Vendor reputation & 15 & 15 & 15 \\
Technical competence & 16 & 18 & 19 \\
Special expertise & 17 & 14 & 16 \\
Systems capabilities & 18 & 17 & 17 \\
Variety of available services & 19 & 20 & 20 \\
Decreased labour problems & 20 & 23 & 22 \\
Personal relationships & 21 & 19 & 18 \\
Decreased asset commitment & 22 & 22 & 23 \\
Early notification of disruptions & 23 & 21 & 21 \\
Increased competition & 24 & 24 & 24 \\
Global capabilities & 25 & 25 & 25 \\
\hline \hline
\end{tabular}

Furthermore, the results of this study will provide recommendations that can be made by the company to obtain efficient results in the cement carrier decision support system in the future.

\section{RESULTS AND DISCUSSION}

The results obtained from this study are the weights of each criterion used. The driver performance variable has a very important role in this study, then followed by expeditor's performance and the last time waiting. The sub criteria that have the greatest value on expeditor criteria are timeliness as we can see in Table 6.

TABLE 4. Percentage Weight of CRITERIA

\begin{tabular}{lc}
\hline \hline \multicolumn{1}{c}{ Criteria } & Percentage Weight \\
\hline Driver's performance & 54.78 \\
Expeditor's performance & 33.92 \\
Waiting Time & 11.3 \\
\hline \hline
\end{tabular}

So this weight is used in the decision support system, which of these systems determines the selection of cement transport trucks based on the calculation of driver performance, expedition performance and waiting time. 
This system will choose different results compared with first in first out (FIFO) system

\section{TABLE 5 .}

PerCentage OF Driver's PeRformance Sub-CRITERIA

\begin{tabular}{cc}
\hline \hline Sub-Criteria & Percentage Weight \\
\hline Timeliness of Delivery & 42 \\
Compliance with Regulations & 29.42 \\
Skills & 6.81 \\
Safety & 21.78 \\
\hline \hline
\end{tabular}

TABLE 6.

Percentage of ExPeditor's Performance Sub-CRITERIA

\begin{tabular}{lc}
\hline \hline \multicolumn{1}{c}{ Criteria } & Percentage Weight \\
\hline Punctuality & 25.75 \\
Service quality & 15.29 \\
Reliability & 11.88 \\
Service speed & 21.81 \\
Technical ability & 8.31 \\
Price & 5.65 \\
Cost reduction & 6.01 \\
Cooperation & 5.29 \\
\hline \hline
\end{tabular}

\section{REFERENCES}

PT. Semen Indonesia, "Reshaping the Future, Annual Report PT Semen Indonesia, Tbk," Gresik, Indonesia, 2017.

[2] I. N. Pujawan and E. R. Mahendrawati, Supply Chain Management. Surabaya: Guna Widya, 2010.
[3] P. Goodwin and G. Wright, Decision Analysis for Management Judgment. Chichester, West Sussex, UK: John Wiley \& Sons Inc, 2004.

[4] M. Marimin, Teknik dan Aplikasi: Pengambilan Keputusan Kriteria Majemuk. Jakarta: PT Grasindo, 2005.

[5] P. Sen and J.-B. Yang, Multiple Criteria Decision Support in Engineering Design. London, UK: Springer, 1998.

[6] D. J. Bowersox, D. J. Closs, and M. B. Cooper, Supply Chain Logistics Management, 4th ed. New York: McGraw-Hill, 2013.

[7] T. Kimura, "The Emergence of Third Party Logistics," Tokyo, Japan, 1998.

[8] A. Aguezzoul, "Third-party logistics selection problem: A literature review on criteria and methods," Omega (United Kingdom), vol. 49. Elsevier Ltd, pp. 69-78, 2014.

[9] F. B. Green, W. Turner, S. Roberts, A. Nagendra, and E. Wininger, "A practitioners perspective on the role of a thirdparty logistics provider," J. Bus. Econ. Res., vol. 6, no. 6, 2008.

[10] Y. Shi, A. Zhang, T. Arthanari, Y. Liu, and T. C. E. Cheng, "Third-party purchase: An empirical study of third-party logistics providers in China," Int. J. Prod. Econ., vol. 171, pp. 189-200, 2016.

[11] A. Aguezzoul, "The Third Party Logistics Selection: A Review of Literature," in International Logistics and Supply Chain Congress, 2007.

[12] E. Turban, J. E. Aronson, and T.-P. Liang, Decision Support Systems and Intelligent Systems. New Jersey: Prentice-hall Inc, 2005.

[13] P. G. . W. Keen and M. S. S. Morton, Decision Support Systems: An Organizational Perspective. Reading, Massachusetts: Addison-Wesley Publishing Company, Inc, 1978.

[14] F. Burstein and C. W. Holsapple, Handbook on Decision Support Systems, Vol 1. Berlin, Heidelberg: Springer, 2008. 